\title{
Varietal response of sunflower Helianthus annus (L) to root-knot nematode Meloidogyne spp and other field pathogens
}

\author{
${ }^{* 1}$ Fabiyi, Oluwatoyin Adenike and ${ }^{2}$ Atolani, Olubunmi \\ ${ }^{* 1}$ Department of Crop Protection, University of Ilorin, Ilorin, Nigeria. \\ ${ }^{2}$ Department of Chemical Sciences, Redeemer's University, Mowe, Nigeria. \\ ABSTRACT
}

\begin{abstract}
Chemical compositions of a plant determine its resistance and vulnerability to pathogens. The varietal susceptibility of sunflower (a good producer of edible and nutritious oil) to Meloidogyne spp and other field pathogens was investigated. Five cultivars of Helianthus annus L, namely France lever, Isanka, Peredovicks, Pwk $E_{5}$ and Sigco 445 were investigated for their susceptibility to Meloidogyne spp, Alternaria leaf spot and virus mosaic. They exhibited different degrees of susceptibility to Alternaria leaf spot, Meloidogyne spp and virus mosaic. Most parameters of growth and yield that is; mean plant height, mean number of leaves, weights of head and seeds at harvest also differ significantly $(p<0.05)$ among the cultivars. France lever appeared to be the least affected by the diseases and consequently exhibited superiority over others in most growth and yield parameters.
\end{abstract}

Keywords: Helianthus annus, Meloidogyne, Alternaria, virus mosaic, allelochemicals, France lever.

\section{INTRODUCTION}

Sunflower, Helianthus annus L, an annual broad leaf herbaceous plant belongs to the family compositae. It is cultivated mainly for its edible oil seed (Kinman, 1963) and was introduced to Nigeria in the sixties to supplement groundnut oil and palm oil as a source of vegetable oil (Ogunremi, 1979). The production of vegetable oils is by far below current demand, since it covers about $10 \%$ of the consumption (El-Fayoumy et al., 1999). Sunflower is considered as one of the most important oil crops in the world today. Therefore, an improvement in the productivity of the crop is highly important, to meet the current shortage of vegetable oils for both home consumption and industrial use. Sunflower seeds have been estimated to have a feed constituent of about $13.77 \%$ digestible crude protein, $14.05 \%$ fibre and $21.30 \%$ digestible oil (Oyenuga, 1968). It is also rich in polyunsaturated fatty acids, which is recommended as a vital part of the diet. Apart from the fatty acids, essential oil and nutritional components are obtained from sunflower oil, the plant also contain some bioactive compounds that have been associated with antibacterial activity this include sesquiterpenes, lactones, annuionones, helibisabonols and heliannuols (Sankaranarayanan et al., 2008). Plant metabolites which include terpenoids, phenolics, carotenoids and allelochemicals have been identified and isolated from the plant leaves, stem and root. Some of the compounds include chlorogenic acid (1), caffeic acid (2), lutein (3), syringic acid (4), vanillic acid (5) ferulic

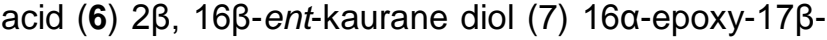
al-ent-kaurane-19-oic acid (Canibe et al., 1999; Ghafar et al., 2001; Suo et al., 2006; Chethan and Gowda, 2010). Many of the compounds reportedly identified have been obtained in high concentrations especially in the root of the plant.

There are many cultivars of this plant which vary in height, size of head and oil content as well as time of maturity. However, all of them are propagated from seed which is normally sown early in the seasons for better performance (Ogunremi, 1979). The cake obtained after extraction is usually a rich source of protein and digestible fibre in livestock meal (Oyenuga, 1968). Like other plants sunflower is susceptible to many pests and diseases, some of which could lead to serious yield reductions. Among such pests are insects and birds, which destroy the seeds in the head especially when it is in the process of maturing. Plant pathogens associated with Sunflower include fungi like Alternaria helianthi, Septoria spp, Verticillium spp, Sclerotia spp and Sclerospora spp which cause diseases on leaves, shoot and root at various stages of growth. 
<smiles>O=C(/C=C/c1ccc(O)c(O)c1)OC1C[C@](O)(C(=O)O)C[C@H](O)[C@H]1O</smiles>

1<smiles>O=C(O)/C=C/c1ccc(O)c(O)c1</smiles>

2<smiles>CC1=C[C@@H](O)CC(C)(C)[C@H]1/C=C/C(C)=C/C=C/C(C)=C/C=C/C=C(C)/C=C/C=C(C)/C=C/C1=C(C)CCCC1(C)C</smiles>

3<smiles>COc1cc(C(=O)O)cc(OC)c1O</smiles><smiles>COc1cc(C(=O)O)ccc1O</smiles><smiles>Cc1cc(/C=C/C(=O)O)ccc1O</smiles>

Caveness (1967) reported the association of Rotylenchus spp, Helicotylenchus spp, Xiphinema spp and Heterodera spp among other nematodes with Sunflower. Ogunremi (1979) observed that low yield of Sunflower in Southern Nigeria could be attributed to severe head rot under high humidity conditions prevalent during period of growth. A similar observation was made earlier in Canada by Hoes (1969) who reported that severe head rot was prevalent in Sunflower cultivated under prolonged wet weather and cool temperature conditions during summers. He also observed that Sunflower cultivars grown on soils with high infestations of Macrophomina phaseolina led to reduced seed yield and seed oil content. Other diseases of Sunflower also include red rust caused by Puccinia helianthi which cause reduction in seed yield and seed oil content (Sackston, 1972). In view of the importance 
of sunflower, and the prospects of its use, coupled with the fact that nematodes and other pathogens are factors militating against optimum yield in the plant it is therefore necessary to investigate the pathogenic effect of Meloidogyne spp and other field pathogens on the plant as they affect some growth and yield parameters.

\section{MATERIALS AND METHODS}

Field Experiment: A field experiment was carried out at the University of Ilorin Teaching and Research farm. The experiment was a randomised block design of five treatments, each replicated four times, thus making a total of twenty (20) plots measuring $25 \mathrm{~m}^{2}$ each. The populations of Meloidogyne spp in the soil was augmented by inoculating with galled roots of okro. Planting was done immediately by sowing three (3) seeds per hole at a spacing of $25 \mathrm{~cm}$ within and $75 \mathrm{~cm}$ between rows. These were later thinned down to a plant per stand three weeks after planting (WAP). Plant height, number of leaves per plant, number of leaves with fungal leaf spots and number of leaves with virus mosaic disease were recorded over a five week period starting from the $8^{\text {th }}$ week after planting. Twenty (20) plant stands which were tagged randomly per plot were used for taking data. Harvesting was done at the $12^{\text {th }}$ week after planting, by uprooting each tagged plant wholly; head weight, seed weight, and root weight were then taken.

Laboratory Experiment:The initial and final nematode populations in the soil were estimated by extracting with the modified Baermann's technique (Whitehead and Hemming, 1965). Nematode populations were then counted under the stereomicroscope. Roots were rated for galls using the $0.5 \%$ scale after Taylor and Sasser (1979).

Data Analysis: All data were subjected to analysis of variance and significant means were separated using the new Duncan's multiple range test at $5 \%$ level of probability.

\section{RESULTS}

Analysis of nematode populations in $200 \mathrm{~g}$ soil revealed that some of the plots were significantly $(p<0.05)$ more infested than the other before planting. Plots grown to France lever had the highest number of nematodes with a mean population of 1547, followed by that of Peredovicks1542; Isanka1303; Pwk $E_{5} 1182$ and Sigco 445, 1016 (Table 1). This indicates that the plants in each plot had the same chance of being infested all things being equal. The population of nematodes in the soil reduced at harvest compared to what it was before planting, plots grown to France lever had the highest apparent populations in the soil even at harvest with a mean of 507, while $\mathrm{PwkE}_{5}$ had the least, there was however significant $(p<0.05)$ differences in nematode populations between some of the plots. All the varieties were susceptible to root knot nematode Meloidogyne spp since all plants were galled either moderately or heavily. France lever had the lowest mean gall index of about 1.25 while Isanka had the highest. The mean plant height of the different varieties are shown in Table 2, all plants increased in height steadily to the 12th week after planting (WAP), but France lever was significantly taller than the other four varieties. Table 3 shows the mean number of leaves among the varieties; France lever had the highest number of leaves throughout the period of observation, while Sigco445 and Isanka had the least. The mean number of leaves that were infected with Alternaria leaf spot is significantly fewer in peredovicks and France lever, while Isanka had the highest. Table 5 depicts the mean number of leaves infected with mosaic and yellowing. Isanka and PwkE $_{5}$ were observed to have significantly higher number of leaves with virus induced mosaic, while France lever had significantly lower number of leaves. France lever also had significantly $(p<0.05)$ higher head, seed, stem and root weight, compared to the other cultivars.

Table1: Nematode population Before Planting, at Harvest and Root gall index

\begin{tabular}{|l|l|l|l|}
\hline Varieties & $\begin{array}{l}\text { Nematode pop. in } \\
\text { 200g soil } \\
\text { planting }\end{array}$ & $\begin{array}{l}\text { Nematode population in 200g soil } \\
\text { at harvest }\end{array}$ & Root gall index \\
\hline France lever & $1547^{\mathrm{a}}$ & $507^{\mathrm{a}}$ & $1.25^{\mathrm{a}}$ \\
Isanka & $1303^{\mathrm{b}}$ & $481^{\mathrm{b}}$ & $4.63^{\mathrm{bc}}$ \\
Peredovicks & $1542^{\mathrm{a}}$ & $463^{\mathrm{c}}$ & $3.18^{\mathrm{b}}$ \\
PwkE & $1182^{\mathrm{c}}$ & $347^{\mathrm{d}}$ & $3.50^{\mathrm{b}}$ \\
Sigco 445 & $1016^{\mathrm{d}}$ & $465^{\mathrm{c}}$ & $3.03^{\mathrm{b}}$ \\
\hline
\end{tabular}

Means followed by the same letter are not significant at $p<0.05$ using Duncan's multiple range test. 
Table2: Mean Plant Height of Sunflower Cultivars under Nematode Infection

\begin{tabular}{|l|l|l|l|l|l|}
\hline Varieties & $\mathbf{8}^{\mathrm{th}}$ WAP & $\mathbf{9}^{\mathrm{IH}}$ WAP & $\mathbf{1 0}^{\mathrm{IH}}$ WAP & $\mathbf{1 1}^{\text {IH }}$ WAP & $\mathbf{1 2}^{\mathrm{IH}}$ WAP \\
\hline France lever & $93.21^{\mathrm{a}}$ & $120.26^{\mathrm{a}}$ & $133.20^{\mathrm{a}}$ & $140.65^{\mathrm{a}}$ & $149.38^{\mathrm{a}}$ \\
Isanka & $54.10^{\mathrm{d}}$ & $81.29^{\mathrm{c}}$ & $99.60^{\mathrm{e}}$ & $113.55^{\mathrm{e}}$ & $115.74^{\mathrm{e}}$ \\
Peredovicks & $81.19^{\mathrm{b}}$ & $121.21^{\mathrm{a}}$ & $125.31^{\mathrm{b}}$ & $137.66^{\mathrm{b}}$ & $142.11^{\mathrm{b}}$ \\
PwkE $_{5}$ & $55.26^{\mathrm{d}}$ & $81.25^{\mathrm{c}}$ & $109.39^{\mathrm{d}}$ & $120.08^{\mathrm{d}}$ & $123.62^{\mathrm{d}}$ \\
Sigco 445 & $62.00^{\mathrm{c}}$ & $89.91^{\mathrm{b}}$ & $119.76^{\mathrm{c}}$ & $128.14^{\mathrm{c}}$ & $129.53^{\mathrm{c}}$ \\
\hline
\end{tabular}

Means followed by the same letter are not significant at $p<0.05$ using Duncan's multiple range test.

Table3: Mean Number of Leaves of Sunflower under Nematode Infection

\begin{tabular}{|l|l|l|l|l|l|}
\hline Varieties & $\mathbf{8}^{\text {th }}$ WAP & $\mathbf{9}^{\text {th }}$ WAP & $\mathbf{1 0}^{\text {th }}$ WAP & $\mathbf{1 1}^{\text {th }}$ WAP & $\mathbf{1 2}^{\text {th }}$ WAP \\
\hline France lever & $17.05^{\mathrm{a}}$ & $19.16^{\mathrm{a}}$ & $21.15^{\mathrm{a}}$ & $22.81^{\mathrm{a}}$ & $22.13^{\mathrm{a}}$ \\
Isanka & $14.33^{\mathrm{c}}$ & $16.66^{\mathrm{c}}$ & $17.01^{\mathrm{c}}$ & $19.14^{\mathrm{c}}$ & $19.00^{\mathrm{bc}}$ \\
Peredovicks & $16.34^{\mathrm{ab}}$ & $18.16^{\mathrm{ab}}$ & $19.10^{\mathrm{b}}$ & $20.46^{\mathrm{b}}$ & $20.23^{\mathrm{b}}$ \\
PukE $_{5}$ & $16.23^{\mathrm{ab}}$ & $18.00^{\mathrm{ab}}$ & $19.16^{\mathrm{b}}$ & $20.13^{\mathrm{b}}$ & $20.59^{\mathrm{b}}$ \\
Sigco 445 & $15.12^{\mathrm{bc}}$ & $16.45^{\mathrm{c}}$ & $17.32^{\mathrm{c}}$ & $19.09^{\mathrm{c}}$ & $19.14^{\mathrm{bc}}$ \\
\hline
\end{tabular}

Means followed by the same letter are not significant at $p<0.05$ using Duncan's multiple range test.

Table4: Incidence of Alternaria Leaf spot Disease on Sunflower under Nematode Infection

\begin{tabular}{|l|l|l|l|l|l|}
\hline Varieties & $\mathbf{8}^{\text {th }}$ WAP & $\mathbf{9}^{\text {th }}$ WAP & $\mathbf{1 0}^{\text {th }}$ WAP & $\mathbf{1 1}^{\text {th }}$ WAP & $\mathbf{1 2}^{\text {th }}$ WAP \\
\hline France lever & $4.26^{\mathrm{a}}$ & $4.17^{\mathrm{a}}$ & $4.59^{\mathrm{a}}$ & $5.32^{\mathrm{a}}$ & $5.47^{\mathrm{a}}$ \\
Isanka & $9.64^{\mathrm{d}}$ & $11.18^{\mathrm{d}}$ & $11.65^{\mathrm{d}}$ & $12.01^{\mathrm{d}}$ & $12.56^{\mathrm{d}}$ \\
Peredovicks & $5.19^{\mathrm{ab}}$ & $6.20^{\mathrm{b}}$ & $6.48^{\mathrm{b}}$ & $7.19^{\mathrm{b}}$ & $7.39^{\mathrm{b}}$ \\
PwkE5 & $7.03^{\mathrm{c}}$ & $8.27^{\mathrm{c}}$ & $8.53^{\mathrm{c}}$ & $9.22^{\mathrm{c}}$ & $9.63^{\mathrm{c}}$ \\
Sigco 445 & $7.15^{\mathrm{c}}$ & $8.33^{\mathrm{c}}$ & $8.74^{\mathrm{c}}$ & $9.17^{\mathrm{c}}$ & $9.50^{\mathrm{c}}$ \\
\hline
\end{tabular}

Means followed by the same letter are not significant at $p<0.05$ using Duncan's multiple range test.

Table5: Incidence of Leaf Mosaic and Yellowing on Sunflower under Nematode Infection

\begin{tabular}{|l|l|l|l|l|l|}
\hline Varieties & $\mathbf{8}^{\text {th }}$ WAP & $\mathbf{9}^{\text {th } W A P}$ & $\mathbf{1 0}^{\text {th }}$ WAP & $\mathbf{1 1}^{\text {th }}$ WAP & $\mathbf{1 2}^{\text {th WAP }}$ \\
\hline France lever & $0.94^{\mathrm{a}}$ & $1.14^{\mathrm{a}}$ & $1.18^{\mathrm{a}}$ & $1.41^{\mathrm{a}}$ & $1.94^{\mathrm{a}}$ \\
Isanka & $3.86^{\mathrm{d}}$ & $3.26^{\mathrm{c}}$ & $3.02^{\mathrm{c}}$ & $3.29^{\mathrm{bc}}$ & $3.81^{\mathrm{b}}$ \\
Peredovicks & $1.44^{\mathrm{ab}}$ & $1.34^{\mathrm{a}}$ & $1.45^{\mathrm{a}}$ & $1.76^{\mathrm{a}}$ & $1.91^{\mathrm{a}}$ \\
PwkE5 & $2.80^{\mathrm{c}}$ & $2.16^{\mathrm{b}}$ & $2.00^{\mathrm{ab}}$ & $2.68^{\mathrm{ab}}$ & $2.05^{\mathrm{a}}$ \\
Sigco 445 & $1.66^{\mathrm{ab}}$ & $1.83^{\mathrm{a}}$ & $1.35^{\mathrm{a}}$ & $1.85^{\mathrm{a}}$ & $1.91^{\mathrm{a}}$ \\
& & & & & \\
\hline
\end{tabular}


Table6: Mean Head, Seed, Stem and Root Weights of Sunflower under Nematode Infection

\begin{tabular}{|l|c|c|c|c|}
\hline Varieties & Head & Seed & Stem & Root \\
\hline France lever & $35.88^{\mathrm{a}}$ & $21.35^{\mathrm{a}}$ & $39.98^{\mathrm{a}}$ & $10.50^{\mathrm{a}}$ \\
Isanka & $18.19^{\mathrm{e}}$ & $13.25^{\mathrm{e}}$ & $17.68^{\mathrm{e}}$ & $3.48^{\mathrm{cd}}$ \\
Peredovicks & $26.83^{\mathrm{b}}$ & $19.00^{\mathrm{b}}$ & $30.14^{\mathrm{b}}$ & $7.63^{\mathrm{b}}$ \\
PwkE $_{5}$ & $18.36^{\mathrm{d}}$ & $15.45^{\mathrm{d}}$ & $20.00^{\mathrm{d}}$ & $4.63^{\mathrm{c}}$ \\
Sigco 445 & $21.11^{\mathrm{c}}$ & $17.13^{\mathrm{c}}$ & $26.32^{\mathrm{c}}$ & $5.60^{\mathrm{c}}$ \\
\hline
\end{tabular}

Means followed by the same letter are not significant at $p<0.05$ using Duncan's multiple range test

\section{DISCUSSION}

The varieties of Sunflower investigated exhibited different responses to Meloidogyne spp and other pathogenic attack during their period of active growth. France lever appeared to be highly resistant to attack by producing significantly higher plant height, number of leaves, fewer numbers of leaves attacked by Alternaria and virus mosaic, and also showing superiority over others in yield parameters such as the head, seed, stem and root weights which were significantly higher than the other cultivars. Studies have indicated that only a few variety of Sunflower are resistant to root-knot nematode Meloidogyne spp. Vinconte (1982) had observed that most sunflower varieties are not highly resistant to Meloidogyne incognita, while Rich and Dunn (1982) reported that though many nematodes reproduce well on the crop, the crop appeared to be tolerant to parasitism by some nematodes including $M$. incognita. In this study, it was observed that the plants were susceptible to attack in varying degrees but some seems more tolerant than the other. This may be attributed to the presence of some bio-active compounds in various amounts in the cultivars.

\section{REFERENCES}

Canibe N, Pedrosa MM, Robredo LM, Knudsen KEB (1999).Chemical composition, digestibility and protein quality of 12 sunflower (Helianthus annuus L) cultivars. Journal of the Science of Food and Agriculture. 79 (13): 1775-1782.

Caveness FE,(1967). Nematodes affecting western region agric, end of tour progress on the nematology project. MANR Western region Nigeria. USAID 135.

Chethan KM and Gowda TV(2010). Sunflower (Helianthus annuus L.) petals: A new biological source of Lutein. Research Journal of Pharmaceutical, Biological and Chemical Sciences. 1(4); 438 -448.

El-Fayoumy ME, Hammad KM, Ramdan HM. (1999). Soil salinity effects on performance of some canola varieties (Brassica napus L.) under calcareous soil conditions at Nubaria region. Alexandria Exchange Science 20, 201-220.
Ghafar A, Saleem B., -Ul-haq A and Qureshi MJ (2001). Isolation and Identification of Allelochemicals of Sunflower (Helianthus annuus L.) International Journal of Agriculture and Biology. Vol. 3, No. 1; 21-22.

Hoes JA, (1969). Sunflower diseases in Manitoba. Can plant disease survive 49: 27.

Kinman MML, (1963). Current status of Sunflower production and research in the possibility of this crop as an oil seed in the united states. USDA MIMEO C.R.13-63.

Ogunremi EA, (1979). Preliminary trials on Sunflower performance in Southern Nigeria. Veg. for the hot humid tropics 40-42.

Oyenuga VA, (1968). Nigerian foods and feeding stuffs pub. Ibadan University press.

Rich JR and Dunn RA, (1982). Pathogenicity and control of nematodes affecting Sunflower in North Central Florida. Plant disease 66 (4): 297-298.

Sackston FD, (1972). Biology of seeds and oil content.Miscellaneous Germany 18-20.

Sankaranarayanan S, Bama $P$, Deccaraman M, Vijayalakshimi M, Murugesan K, Kalaichelvan PT and Arumugam $P$ (2008). Isolation and Characterisation of bio-active and antibacterial compounds from Helianthus annus L. Indian Journal of Experimental Biology vol 46 831-835.

Suo MR, Yang JS, Lu Y, Wu L, ZHENG QT, (2006). Two New Diterpenes from Helianthus annuus L. Chinese Chemical Letters, 17 (1): 45-48.

Taylor L and Sasser JN, (1978). Biology, Identification and Control of root-knot nematodes Meloidogyne spp IMP, Dept of plant pathology MCSU, Raleigh.111.

Vinconte PC, (1982). Root-knot nematode problems of Sunflower. Proc. of research and plan. cont.on rootknot nematode.

Whitehead AG and Hemming JR, (1965). A comparison of some quantitative methods of extracting small vermiform nematodes from soil. Ann.Appl.Biol., 55 2538. 